\title{
A FRESHWATER LAKE SAGA: CARBON ROUTING WITHIN THE AQUATIC FOOD WEB OF LAKE SCHWERIN
}

\author{
Ricardo Fernandes ${ }^{1,2,3}$ • Alexander Dreves ${ }^{1}$ Marie-Josée Nadeau ${ }^{1,2}$ • Pieter M Grootes ${ }^{1,2}$
}

ABSTRACT. Recently, several case studies have demonstrated the presence of human radiocarbon dietary reservoir effects in inland contexts. Freshwater reservoir effects present a high degree of variability, making it difficult to define local reservoir effect reference values necessary for correcting chronologies based on ${ }^{14} \mathrm{C}$ dating of human bone material. Here, we investigate the hypothesis that ${ }^{14} \mathrm{C}$ ages of edible freshwater species are delimited by the ${ }^{14} \mathrm{C}$ ages of the main water carbon pools (DIC, POC, and DOC).

\begin{abstract}
Water, plant, algae, bivalve, and fish samples were collected from lakes Schwerin and Ostorf (Germany). ${ }^{14} \mathrm{C}$ and isotopic measurements were performed on the floral and faunal species and on water DIC, POC, and DOC. The results demonstrate the potential of the study area for large and variable freshwater reservoir effects. In the case of Lake Schwerin, the working hypothesis was verified as the ${ }^{14} \mathrm{C}$ ages of faunal and floral species were delimited by the ${ }^{14} \mathrm{C}$ ages of water DIC and POC, probably associated with 2 extreme categories of food chains (grazing and detritus). While the results obtained confirm the working hypothesis and suggest a relatively straightforward interpretation, further research is necessary to investigate possible spatial and seasonal variations.
\end{abstract}

\section{INTRODUCTION}

Radiocarbon dating is the method most widely used within archaeology to establish absolute chronologies, often relying on the dating of human bone material. Humans obtain their carbon via their food; as a result, the ${ }^{14} \mathrm{C}$ concentration in their bodies reflects the ${ }^{14} \mathrm{C}$ concentration of the plants and/or animals they eat. If some of the food consumed has a ${ }^{14} \mathrm{C}$ concentration different from that of the atmosphere, that is, a reservoir age, humans will also show a diet-related reservoir age and generally be ${ }^{14} \mathrm{C}$ dated too old. The reservoir effect, defined as the ${ }^{14} \mathrm{C}$ age offset between the aquatic and atmospheric reservoir, is referred to as the marine reservoir effect (MRE) when considering the ocean, and the freshwater reservoir effect (FRE) for freshwater aquatic reservoirs (Ascough et al. 2004, 2010). A MRE average reference value, or global marine reservoir effect, of $400 \mathrm{yr}$ is usually applied to correct ${ }^{14} \mathrm{C}$ measurements from marine samples, which is then corrected for local variations both in time and space (Gordon and Harkness 1992; Ascough et al. 2004). Freshwater reservoir ages depend on many parameters, such as rainfall, topography, vegetation, presence of carbonates in the geological background, residence times of groundwater, and glacier meltdown (Olsson 1980; Landmeyer and Stone 1995; Lanting and van der Plicht 1998; Geyh 2000; Levin and Hesshaimer 2000; Hall and Henderson 2001; Ascough et al. 2010). Together, these factors determine the mixing of carbon compounds of different origin, age, and isotopic composition. Thus, freshwater reservoir ages are highly variable in space and time, and may reach much larger ${ }^{14} \mathrm{C}$ offsets than marine reservoirs, often of several thousands of years (Geyh et al. 1998; Geyh 2000; Hall and Henderson 2001; Zhou et al. 2009; Ascough et al. 2010).

Recently, several case studies from inland locations have compared ${ }^{14} \mathrm{C}$ dates of human remains with independent and secure reference dates and revealed significant offsets (Lanting and van der Plicht 1998; Cook et al. 2001; Shishlina et al. 2007, 2009; Lillie et al. 2009; Higham et al. 2010; Olsen et al. 2010; Fernandes et al. 2012a,b). In some cases, human remains were ${ }^{14} \mathrm{C}$ dated several

\footnotetext{
${ }^{1}$ Leibniz Laboratory for Radiometric Dating and Isotope Research, Christian Albrecht University, Kiel, Germany.

${ }^{2}$ Graduate School Human Development in Landscapes, Christian Albrecht University, Kiel, Germany.

${ }^{3}$ Corresponding author. Email: rfernandes@gshdl.uni-kiel.de.
} 


\section{$R$ Fernandes et al.}

hundreds of years older than well-established reference dates. Estimates on the human intake of aquatic foods generally rely on isotopic measurements on bone collagen, usually $\delta^{13} \mathrm{C}$ and $\delta^{15} \mathrm{~N}$. In the case of a possible marine diet, the $\delta^{13} \mathrm{C}$ collagen signal provides a distinction between marine and terrestrial $\left(\mathrm{C}_{3}\right)$ food groups (Schoeninger et al. 1983). Simple linear models have been developed to quantify the contribution of marine protein through measurement of $\delta^{13} \mathrm{C}$ collagen values which are compared with marine and terrestrial isotopic end-members (Arneborg et al. 2000; Dewar and Pfeiffer 2010). In freshwater contexts, the $\delta^{13} \mathrm{C}$ values of aquatic food sources are more varied, often overlapping with terrestrial sources. The measurement of $\delta^{15} \mathrm{~N}$ in collagen provides an alternative dietary proxy. There is a general relationship between higher $\delta^{15} \mathrm{~N}$ values and higher trophic levels in food chains. Aquatic food chains generally have a higher number of intermediate trophic levels, when compared with terrestrial food chains. This results in typically higher $\delta^{15} \mathrm{~N}$ values for potential aquatic food groups (Schoeninger and DeNiro 1984; Post 2002; Hedges and Reynard 2007).

Assuming that estimates on the human intake of aquatic foods are accurate, it is also necessary to establish the reservoir age of the foods. This may represent a difficult problem, as recent results have demonstrated that reservoir ages of edible freshwater species can be very variable, even when these are collected within a small area of the same water course and within a short timespan (Fischer et al. 2007; Ascough et al. 2011; Fernandes et al. 2012b; Keaveney and Reimer 2012; Philippsen 2012). Freshwater food webs can have a high complexity with large interspecies-and in some cases, also intraspecies - differences in dietary preferences. This implies that, in order to define the possible range of reservoir ages in aquatic species, it is necessary to characterize the ${ }^{14} \mathrm{C}$ ages of the main carbon pools at the base of the food web. These are represented by the dissolved inorganic carbon (DIC), particulate organic matter (POC), and dissolved organic matter (DOC). Some aquatic species might also have a terrestrial component in their diet. DIC occurs in ionic form as bicarbonate, carbonate, carbonic acid, or as dissolved gaseous carbon dioxide (Hope et al. 1994); the predominant fraction being determined by the $\mathrm{pH}$ regime. The amount of $\mathrm{CO}_{2}$ dissolved in the water depends, assuming equilibrium with the atmosphere, on its partial pressure, which is determined by uptake from the atmosphere, photosynthesis, and from the oxidation of organic matter (Drimmie et al. 1991; McNichol et al. 1994; Geyh 2000). Photosynthetic aquatic plants and algae acquire their carbon both from water dissolved carbon dioxide and bicarbonate (Smith and Walker 1980; Maberly and Spence 1983). Aquatic organic carbon may originate from terrestrial, including anthropogenic, sources (allochthonous), or be produced in situ as in the case of phytoplankton (autochthonous; Hope et al. 1994). Here, we follow a classification of organic matter based on particle size (Hope et al. 1994). POC corresponds to a particle size between $1 \mathrm{~mm}$ and $0.45 \mu \mathrm{m}$ and includes a mixture of different carbon sources (e.g. phytoplankton, zooplankton, bacteria, detritus; Poulain et al. 2010). DOC corresponds to a particle size smaller than $0.45 \mu \mathrm{m}$ (e.g. humic acids, fulvic acids, fatty acids, hydrocarbons; Hope et al. 1994).

The objective of the research presented here was to test the hypothesis that the ${ }^{14} \mathrm{C}$ concentrations of selected faunal species would be constrained within the ${ }^{14} \mathrm{C}$ concentrations of aquatic carbon pools (POC, DOC, and DIC). Samples were collected from lakes Schwerin and Ostorf, in the vicinity of a

prehistoric cemetery, where the existence of human dietary reservoir effects has been demonstrated (Olsen et al. 2010). All collected samples were ${ }^{14} \mathrm{C}$ dated and, in some instances, isotopic measurements $\left(\delta^{13} \mathrm{C}\right.$ and $\left.\delta^{15} \mathrm{~N}\right)$ were done to help in the interpretation of ${ }^{14} \mathrm{C}$ results. 


\section{Routing Within Aquatic Food Web of Lake Schwerin}

\section{ENVIRONMENTAL DESCRIPTION OF STUDY AREA}

Lake Schwerin (area $\sim 62 \mathrm{~km}^{2}$, maximum depth $\sim 52 \mathrm{~m}$ ), situated immediately to the east of the city of Schwerin, is part of the Mecklenburg Lake District, a large and complex lake system located mostly within the central and southern part of the state of Mecklenburg-Vorpommern, Germany (Figure 1). The lake is divided into 2 major water bodies, the Outer Lake to the north and the Inner Lake to the south, with a narrow connection (Figure 1). The surrounding area is dotted with several smaller lakes, including Lake Ostorf (area $\sim 1.3 \mathrm{~km}^{2}$ ), $1.5 \mathrm{~km}$ southwest of Lake Schwerin.

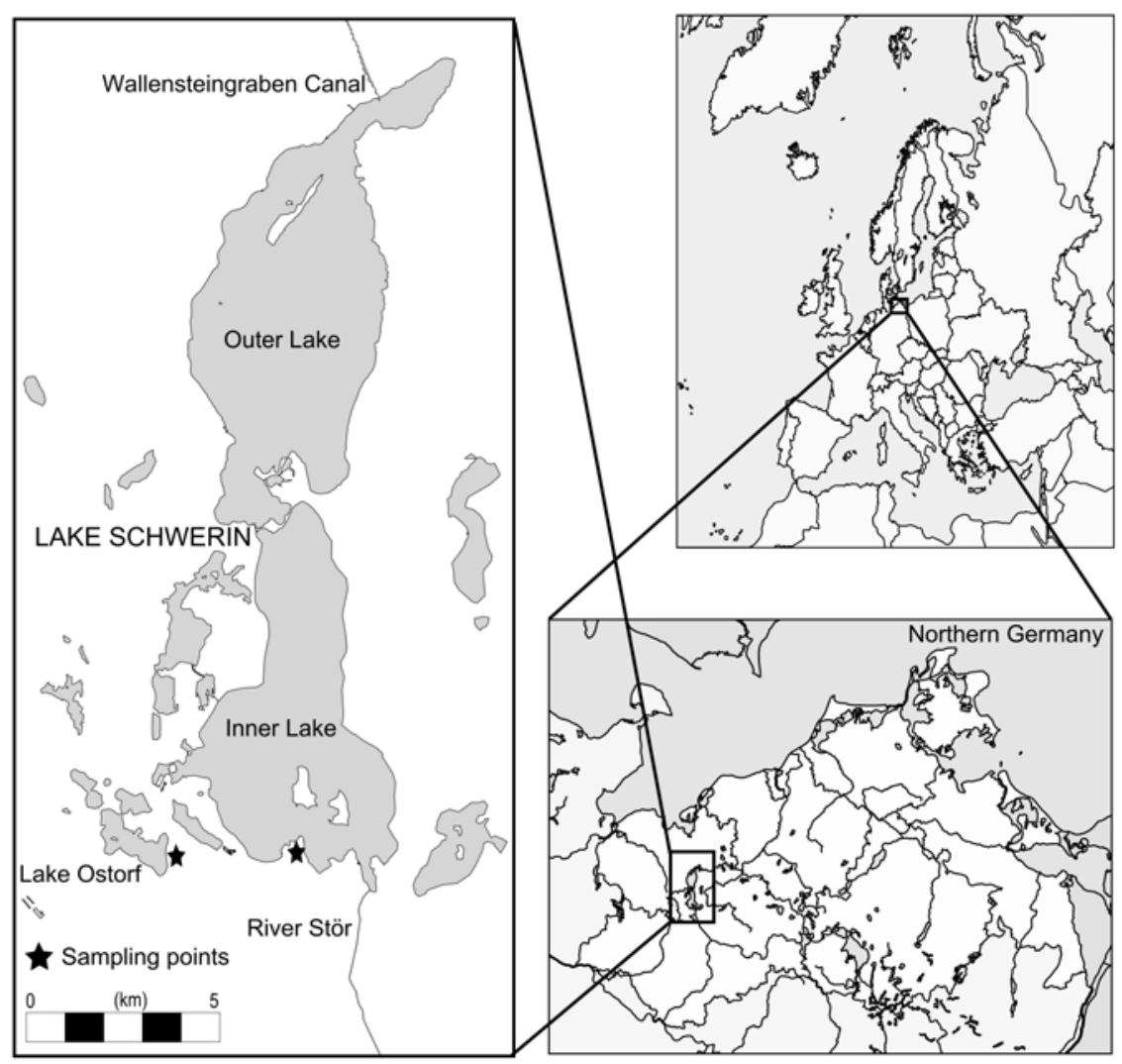

Figure 1 Study area. The stars mark the collection points of samples from lakes Schwerin and Ostorf. Fish samples (eel, bream, and pike) were fished from the Inner Lake.

The geology of the region is characterized by deep alternating deposits of sandy sediments and till layers, including carbonate rocks, deposited in ice advance and retreat events during the Weichselian glaciation (Katzung 2004; Krienke and Obst 2011). Lake Schwerin is a tongue-like basin surrounded by ground moraine relief and deposits and bounded to the south by a terminal moraine (Hübner et al. 1979; Katzung 2004; Krienke and Obst 2011).

The water of Lake Schwerin has an average turnover period of 11 yr. Major outflows are the channelized rivers Wallensteingraben to the north and the Stör at the southern tip. Major sources of water inflow into Lake Schwerin are groundwater and the small Aubach River (Nixdorf et al. 2004). Lake Schwerin is an eutrophic lake with high levels of nutrients, phosphorus, and nitrogen, resulting from farming activities that occupy $48 \%$ of the surrounding area (Nixdorf et al. 2004). The lake contains 


\section{$R$ Fernandes et al.}

a variety of algae, phytoplankton, zooplankton, mollusks, and fish species (Nixdorf et al. 2004; Mehner et al. 2005).

\section{MATERIAL}

All samples were collected within a 24-hr period in September 2011. Fish specimens (bream, eel, and pike) were fished from the Inner Lake of Lake Schwerin. Zebra mussel, water plant, and algae samples were collected from a shore location $\left(53^{\circ} 36^{\prime} 32.33^{\prime \prime} \mathrm{N}, 11^{\circ} 28^{\prime} 5.90^{\prime \prime} \mathrm{E}\right)$ in the Inner Lake (Figure 1). A single specimen of live zebra mussel was collected from a shore location $\left(53^{\circ} 36^{\prime} 19.09^{\prime \prime} \mathrm{N}\right.$, $11^{\circ} 24^{\prime} 57.92^{\prime \prime}$ ) at Lake Ostorf (Figure 1).

\section{METHODS}

To remove adhering dust and detrital carbonate as well as organic surface coating, bivalve wholehalf shell samples were first cleaned with $30 \% \mathrm{H}_{2} \mathrm{O}_{2}$ in an ultrasonic bath, followed by a second cleaning step with $15 \% \mathrm{H}_{2} \mathrm{O}_{2}$ in an ultrasonic bath. Shell samples were milled into a fine powder and 2 aliquots were collected for ${ }^{14} \mathrm{C}$ and $\delta^{13} \mathrm{C}$ analysis. Sample $\mathrm{CO}_{2}$ for ${ }^{14} \mathrm{C}$ dating was liberated with $100 \% \mathrm{H}_{3} \mathrm{PO}_{4}$ at $90{ }^{\circ} \mathrm{C}$. The $\mathrm{CO}_{2}$ was collected in a sample bottle using liquid nitrogen.

Carbon isotopic composition $\left(\delta^{13} \mathrm{C}\right)$ of bivalve shells was measured at the Leibniz Laboratory for Radiometric Dating and Isotope Research (Kiel, Germany). Individual powder samples of bivalve carbonate were acidified in $100 \% \mathrm{H}_{3} \mathrm{PO}_{4}$ at a constant $75^{\circ} \mathrm{C}$ using an automated Kiel I (prototype) carbonate preparation device coupled to a Finnigan MAT 251 mass spectrometer. Replicate analyses of standards yielded a precision better than 0.05\% for internal laboratory and NBS-19 (National Institute of Standards and Technology, NIST SRM 8544) standards.

Isotopic measurements on bivalve and fish flesh were performed at the stable isotope laboratory of the Max-Planck-Institute for Evolutionary Anthropology (Leipzig, Germany). Stable isotope analysis and concentration measurements of carbon and nitrogen were performed with a Delta XP (ThermoFinnigan, Bremen, Germany) isotope ratio mass spectrometer (IRMS), coupled to a Flash elemental analyzer. Stable isotope ratios are expressed in the conventional delta notation $\left(\delta^{13} \mathrm{C}\right.$ and $\delta^{15} \mathrm{~N}$ ) relative to the standards VPDB (Vienna PeeDee belemnite standard) and AIR (atmospheric nitrogen). Precision was better than $\pm 0.2 \%$.

Water samples for water DIC analysis were carefully collected to prevent splashing that could result in $\mathrm{CO}_{2}$ losses/fractionation or atmospheric exchange. The samples were poisoned with a mercury chloride solution ( $0.2 \mathrm{~mL} \mathrm{HgCl} 2$ per $100 \mathrm{~mL}$ water) to stop bacterial activity and algae growth. A clean glass container was fully filled and sealed with a cap coated with Apiezon grease and covered with PVC tape. Water samples were transferred to precleaned crimp sample bottles and attached to the Kiel DICI II Device operated online with a Finnigan Delta E dual-inlet gas IRMS (Erlenkeuser et al. 2003). Water samples were acidified by adding $30 \% \mathrm{H}_{3} \mathrm{PO}_{4}$ and the $\mathrm{CO}_{2}$ was flushed off with $\mathrm{N}_{2}$. The working gas was calibrated against the NBS 19 standard. Standard error of the analytical procedure is better than $0.08 \%$.

The water sample ( $\sim 3 \mathrm{~L}$ ) collected for DOC/POC analysis was acidified to $\mathrm{pH} 1$ to dissolve carbonates and stored at $4{ }^{\circ} \mathrm{C}$ in the dark prior to further treatment. The sample was filtered through suction using a water jet pump, first using a 1-mm quartz filter to remove larger fractions. It was filtered again with a precombusted silver filter $\left(900^{\circ} \mathrm{C}\right)$ to obtain water POC $(\geq 0.45 \mu \mathrm{m}$ and $<1 \mathrm{~mm})$ and DOC $(<0.45 \mu \mathrm{m})$ fractions. Freeze-dried fish, mussel flesh, POC, and DOC samples were flamesealed in quartz tubes together with copper oxide and silver and heated to $900{ }^{\circ} \mathrm{C}$ for combustion. 


\section{Routing Within Aquatic Food Web of Lake Schwerin}

Sample $\mathrm{CO}_{2}$ was reduced to graphite with $\mathrm{H}_{2}$ at $600{ }^{\circ} \mathrm{C}$ over $2 \mathrm{mg}$ of an iron catalyst. The iron/carbon mixture was pressed as a pellet into a target holder for accelerator mass spectrometry (AMS) measurement in a 3MV Tandetron from High Voltage Engineering Europa (HVEE) equipped with a cesium sputter ion source and a separator/recombinator for simultaneous injection of the 3 isotopic carbon beams (Nadeau et al. 1997, 1998). The ${ }^{14} \mathrm{C}$ concentration of the sample was measured by comparing the simultaneously collected ${ }^{14} \mathrm{C},{ }^{13} \mathrm{C}$, and ${ }^{12} \mathrm{C}$ beams from each sample with those of the oxalic acid II standard. For determination of the measurement uncertainty, both the counting statistics of the ${ }^{14} \mathrm{C}$ measurement and the variability of the 8-12 interval results that, together, make up 1 measurement are observed and the larger of the two is adopted as the measuring uncertainty (Nadeau et al. 1998, 2001).

For POC, DOC, water plant, and algae, $\delta^{13} \mathrm{C}$ values were determined using the AMS system with a precision better than $0.4 \%$ and an accuracy of $\sim 1 \%$, thus lacking the accuracy of IRMS determined values.

\section{RESULTS AND DISCUSSION}

${ }^{14} \mathrm{C}$ and isotopic results for lakes Schwerin and Ostorf are shown in Table 1; the results for Lake Schwerin are also shown in Figure 2. The results demonstrate large freshwater reservoir effects in the study area. In the case of Lake Schwerin, faunal species present a wide range in ${ }^{14} \mathrm{C}$ ages, from $190 \pm 30 \mathrm{yr}$ for bream (KIA-46305) up to $625 \pm 25 \mathrm{yr}$ for the smaller eel (KIA-46307). However, this contrasts with the other ${ }^{14} \mathrm{C}$ measurements on faunal and floral material from Lake Schwerin, which all present similar ${ }^{14} \mathrm{C}$ concentrations. In Lake Ostorf, in spite of its close proximity to Lake Schwerin, the ${ }^{14} \mathrm{C}$ ages for the single zebra mussel specimen (KIA-46311), both in the flesh (1120 \pm $20 \mathrm{yr})$ and shell (1060 $\pm 30 \mathrm{yr}$ ), are significantly larger than those observed in Lake Schwerin.

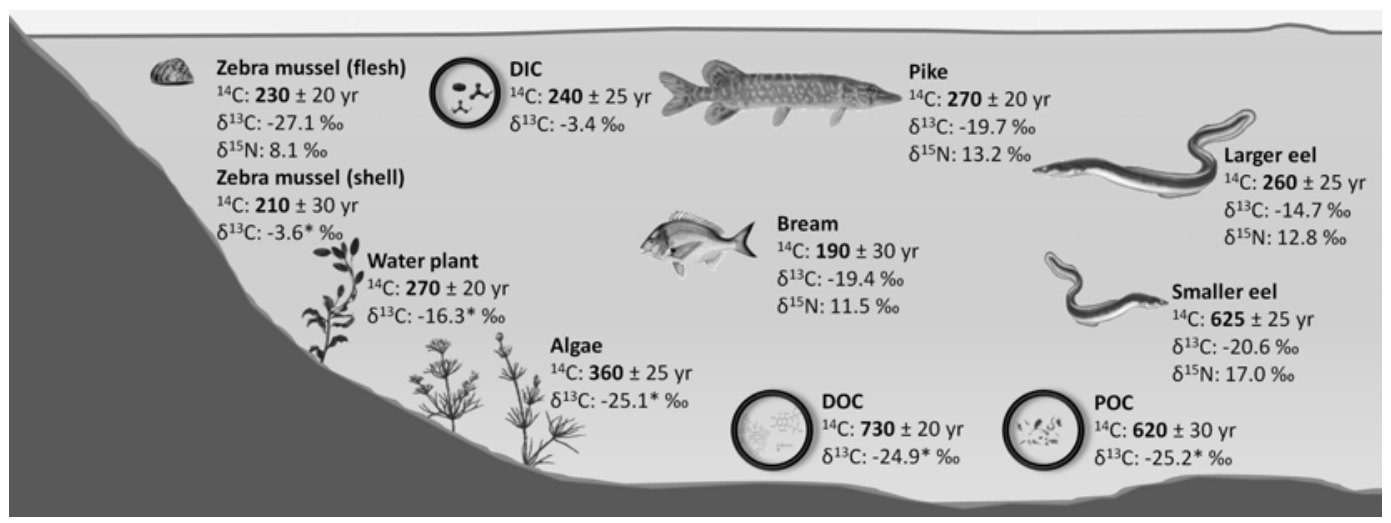

Figure 2 Radiocarbon and isotopic results for samples collected from Lake Schwerin. ${ }^{14} \mathrm{C}$ measurements are expressed as conventional ages (yr BP), while isotopic results are expressed in standard per mil notation. Asterisks mark $\delta^{13} \mathrm{C}$ measurements done with the AMS system.

The ${ }^{14} \mathrm{C}$ results are consistent with archaeological results that demonstrated the existence of large human dietary reservoir effects in prehistoric populations (Olsen et al. 2010). Furthermore, since measured reservoir ages need to be corrected for the atmospheric ${ }^{14} \mathrm{C}$ concentration at the time of collection, estimated at $\sim 104$ pMC for 2011 (I Levin, personal communication) or $\sim 320 \mathrm{yr}$, this leads to apparent ${ }^{14} \mathrm{C}$ flesh ages up to $~ 945 \mathrm{yr}$ for Lake Schwerin and $1440 \mathrm{yr}$ for Lake Ostorf. However, reservoir effects may have differed in the past given not only anthropogenic influences but also climatic, geological, and hydrological changes. 


\section{$R$ Fernandes et al.}

Table $1{ }^{14} \mathrm{C}$ and isotopic results for samples collected at lakes Schwerin and Ostorf. Asterisks denote $\delta^{13} \mathrm{C}$ measurements done with the AMS system.

\begin{tabular}{|c|c|c|c|c|c|c|c|c|}
\hline $\begin{array}{l}\text { Sample } \\
\text { description }\end{array}$ & Species or genus & $\begin{array}{l}\text { Lake } \\
\text { location }\end{array}$ & $\begin{array}{l}\text { Sample } \\
\text { code } \\
\text { (KIA-) }\end{array}$ & $\begin{array}{l}\text { Length/ } \\
\text { particle } \\
\text { size }\end{array}$ & $\begin{array}{l}\text { Conven- } \\
\text { tional age } \\
(\mathrm{yr} \mathrm{BP})\end{array}$ & $\mathrm{pMC}$ & $\begin{array}{l}\delta^{13} \mathrm{C} \\
(\% \text { o } \\
\text { VPDB) }\end{array}$ & $\begin{array}{l}\delta^{15} \mathrm{~N} \\
(\% o \\
\text { AIR) }\end{array}$ \\
\hline Pike & Esox lucius & Schwerin & 46304 & $63 \mathrm{~cm}$ & $270 \pm 20$ & $96.74 \pm 0.26$ & -19.7 & 13.2 \\
\hline Bream & Abramis brama & Schwerin & 46305 & $38 \mathrm{~cm}$ & $190 \pm 30$ & $97.64 \pm 0.37$ & -19.4 & 11.5 \\
\hline Larger eel & Anguilla anguilla & Schwerin & 46306 & $63 \mathrm{~cm}$ & $260 \pm 25$ & $96.79 \pm 0.28$ & -14.7 & 12.8 \\
\hline Smaller eel & Anguilla anguilla & Schwerin & 46307 & $58 \mathrm{~cm}$ & $625 \pm 25$ & $92.54 \pm 0.26$ & -20.6 & 17.0 \\
\hline $\begin{array}{l}\text { Flesh of ze- } \\
\text { bra mussel }\end{array}$ & $\begin{array}{l}\text { Dreissena poly- } \\
\text { morpha }\end{array}$ & Schwerin & 46310 & - & $230 \pm 20$ & $97.23 \pm 0.22$ & -27.1 & 8.1 \\
\hline $\begin{array}{l}\text { Shell of zebra } \\
\text { mussel }\end{array}$ & $\begin{array}{l}\text { Dreissena poly- } \\
\text { morpha }\end{array}$ & Schwerin & 46310 & $2 \mathrm{~cm}$ & $210 \pm 30$ & $97.41 \pm 0.31$ & -3.6 & - \\
\hline Water plant & Potamogeton & Schwerin & 46308 & - & $270 \pm 20$ & $96.69 \pm 0.26$ & $-16.3^{*}$ & - \\
\hline Algae & Chara & Schwerin & 46309 & - & $362 \pm 25$ & $95.59 \pm 0.29$ & $-25.1^{*}$ & - \\
\hline DIC & - & Schwerin & 45882 & - & $240 \pm 25$ & $97.04 \pm 0.29$ & $-3.4^{*}$ & - \\
\hline POC & - & Schwerin & 45882 & $\begin{array}{l}>0.45 \mu \mathrm{m} \\
<1 \mathrm{~mm}\end{array}$ & $620 \pm 30$ & $92.57 \pm 0.31$ & $-25.2^{*}$ & - \\
\hline DOC & - & Schwerin & 45882 & $<0.45 \mu \mathrm{m}$ & $730 \pm 20$ & $91.33 \pm 0.21$ & $-24.9 *$ & - \\
\hline $\begin{array}{l}\text { Flesh of ze- } \\
\text { bra mussel }\end{array}$ & $\begin{array}{l}\text { Dreissena poly- } \\
\text { morpha }\end{array}$ & Ostorf & 46311 & - & $1120 \pm 20$ & $87.02 \pm 0.24$ & -27.8 & 14.6 \\
\hline $\begin{array}{l}\text { Shell of zebra } \\
\text { mussel }\end{array}$ & $\begin{array}{l}\text { Dreissena poly- } \\
\text { morpha }\end{array}$ & Ostorf & 46311 & $1.5 \mathrm{~cm}$ & $1060 \pm 30$ & $87.66 \pm 0.31$ & -7.5 & - \\
\hline
\end{tabular}

Here, we do not investigate large-scale temporal changes of local reservoir effects, but try to understand, for a limited time period, how specimen ${ }^{14} \mathrm{C}$ concentration differences are associated with the food web structure. Within aquatic ecosystems, there are 2 major categories of food chains: grazing and detritus (Attayde and Ripa 2008). Detritus refers to non-living organic matter and constitutes the major component of POC (Pomeroy 1980). However, the principal contributor to non-living organic matter is DOC, which is consumed by bacteria and fungi (Mann 1988; Wetzel 1995). Detritivores and decomposers include certain filter feeders (e.g. mussels), lower trophic level zooplankton, and invertebrates such as insect larvae (e.g. chironomid larvae; Ladle et al. 1972; Armitage et al. 1995). These species are consumed by higher trophic level species such as carnivorous zooplankton and planktivores (e.g. small fishes), which are then in turn consumed by larger piscivores. In a grazing or benthic food chain, primary producers (e.g. phytoplankton and aquatic plants) are consumed by primary consumers or herbivores, which in turn are consumed by secondary consumers or primary carnivores (Havens and East 1997).

The grazing and detritus food chains categories represent 2 ideal extremes. In real freshwater environments, there are couplings between the 2 categories forming complex food webs where aquatic resources are explored using generalist or specialist strategies (Attayde and Ripa 2008). ${ }^{14} \mathrm{C}$ results for Lake Schwerin suggest clearly separated grazing and detritus food chains (Figure 2). ${ }^{14} \mathrm{C}$ ages of water plant (KIA-46305), algae (KIA-46309), zebra mussel (KIA-46310), bream (KIA-46305), pike (KIA-46304), and the larger eel (KIA-46306) are similar to the ${ }^{14} \mathrm{C}$ age of water DIC (KIA-45882) at $240 \pm 25 \mathrm{yr}$. In contrast, the smaller eel (KIA-46307) has a ${ }^{14} \mathrm{C}$ age within $1 \sigma$ of water POC (KIA45882 ) at $620 \pm 30 \mathrm{yr}$. These results require a careful discussion of individual specimens and samples.

Water plant, zebra mussel, larger eel, bream, and pike have ${ }^{14} \mathrm{C}$ ages within a $1 \sigma$ range of the ${ }^{14} \mathrm{C}$ age of water DIC. The algae ${ }^{14} \mathrm{C}$ age is outside the $1 \sigma$ range; however, there were observable difficulties in separating algae from small organic particles during sample pretreatment. Thus, the older algae ${ }^{14} \mathrm{C}$ age is most likely due to the presence of POC in the sample. Furthermore, zebra mussels are 


\section{Routing Within Aquatic Food Web of Lake Schwerin}

well-known phytoplankton consumers (Baker et al. 1998) and the agreement of zebra mussel ${ }^{14} \mathrm{C}$ ages with those of water DIC and water plant suggest that indeed algae were contaminated by POC.

Bivalves are filter feeders and may obtain their food from phytoplankton, bacteria, POC, and DOC. Metabolic carbon is used to synthesize bivalve flesh (Bayne et al. 1993; Cranford and Hill 1999; Vaughn and Hakenkamp 2001; Vuorio et al. 2007; Poulain et al. 2010). Bivalve shells derive their carbon primarily from the water dissolved inorganic carbon (DIC), although in some species a significant portion of shell carbon may also be derived from metabolic carbon (Gillikin et al. 2006, 2009; Franck et al. 2010; Poulain et al. 2010). The good agreement between Lake Schwerin's zebra mussel shell and flesh ${ }^{14} \mathrm{C}$ dates indicates that the specimen did not uptake significant amounts of DOC or POC, in contrast with other literature examples (Roditi et al. 2000; Fernandes et al. 2012b). This is probably due to the high eutrophication level of Lake Schwerin and the availability of abundant phytoplankton biomass. The length of the zebra mussel shell $(2 \mathrm{~cm})$ indicates that it had reached adulthood and that the part of the shell sampled most likely corresponds to several growth seasons (Allen et al. 1999). Thus, the agreement of ${ }^{14} \mathrm{C}$ concentrations of zebra mussel shell with its flesh and that of adult fish specimens indicates that potentially different flesh turnover rates (Weidel et al. 2011) are not readily visible. This could suggest that the water DIC values are relatively constant both spatially and temporally with the latter, which is supported by the long average water turnover period of the lake (11 yr). However, a similar previous study on Lake Superior exhibited some spatial and seasonal variations of water DIC ${ }^{14} \mathrm{C}$ concentrations (Zigah et al. 2012). Therefore, it is necessary to consider the hypothesis that the selected sampling area and period coincidentally provided a water DIC ${ }^{14} \mathrm{C}$ concentration similar to the seasonal and spatial average.

Bream is a member of the Cyprinidae family, which includes carps and minnows. Breams are generalist feeders and can, for instance, feed on plants, invertebrates, and bivalves (Lammens et al. 1992; Nagelkerke and Sibbing 1996; Tierney et al. 1999). The $\delta^{15} \mathrm{~N}$ value for bream flesh (11.5\%) is $\sim 3 \%$ above that of zebra mussel flesh (8.1\%) taken as baseline for pelagic consumption. This represents 1 trophic level difference (Post 2002). However, the flesh $\delta^{13} \mathrm{C}$ value of bream $(-19.7 \%)$, when considering a trophic level enrichment of $\sim 1 \%$ (Fry and Sherr 1984), would suggest that zebra mussels with a considerably more negative $\delta^{13} \mathrm{C}$ value (-27.1\%o) did not represent a significant contribution to the specimen diet. Breams may also supplement their diet with terrestrial insects (Kennedy and Fitzmaurice 1968). This could explain the slightly younger ${ }^{14} \mathrm{C}$ age of bream flesh when compared with the pike or the larger eel.

Pike is a predator that feeds on smaller fishes, but may also feed on crustaceans or insects (Frost 1954; Lorenzoni et al. 2002). The $\delta^{15} \mathrm{~N}$ value for pike flesh (13.2\%) is not greatly elevated when compared with that of bream (11.5\%o), representing half a trophic level difference. This specimen might thus also have consumed a significant amount of invertebrates (Beaudoin et al. 1999; Venturelli and Tonn 2005).

Eel populations are often made up of individual specialists (Barak and Mason 1992; Harrod et al. 2005; Harrod and Grey 2006). They are also relevant for the human dietary reservoir effect as they represented an important food source in prehistoric northern Europe (Robson et al. 2012). Eels usually become more piscivorous as they grow, and some studies have shown a correlation between eel size and $\delta^{15} \mathrm{~N}$ values (Dörner and Benndorf 2003; Harrod and Grey 2006; Robson et al. 2012). However, in our study, the smaller eel has a $\delta^{15} \mathrm{~N}$ value (17.0\%) over 1 trophic level higher than the larger eel $\left(12.8 \%\right.$ ). The $\delta^{15} \mathrm{~N}$ value of the larger eel is similar to that of the pike, placing them at a similar trophic level. However, the larger eel has a higher $\delta^{13} \mathrm{C}$ value $(-14.7 \%)$ when compared with the pike (-19.7\%). This could be the result of feeding in a different location (e.g. littoral) or a specialization in herbivores feeding on floral species that have higher $\delta^{13} \mathrm{C}$ values, such as those 


\section{$R$ Fernandes et al.}

observed for the water plant specimen $(-16.3 \%)$. The ${ }^{14} \mathrm{C}$ results for the smaller $(625 \pm 25 \mathrm{yr})$ and the larger eel ( $260 \pm 25 \mathrm{yr}$ ) show a clear difference. While the value for the smaller eel is similar to that of the water POC (620 $\pm 30 \mathrm{yr}$ ), the larger eel shows a ${ }^{14} \mathrm{C}$ value similar to that of the water DIC ( $240 \pm 25 \mathrm{yr}$ ). This clearly suggests that the larger eel is part of a grazing food chain while the smaller eel is specializing on planktivorous organisms. Previous studies show that it is unlikely that the smaller eel was directly consuming zooplankton; however, eels may consume large amounts of small planktivorous crustaceans (e.g. Asellus) or carnivorous insect larvae (e.g chironomids; Lammens et al. 1985; Barak and Mason 1992). The presence of these species in Lake Schwerin has been attested (Nixdorf et al. 2004). Furthermore, high $\delta^{15} \mathrm{~N}$ values in zooplankton may occur due to the multiple trophic levels within a microbial loop (Hessen et al. 1990), in which case zooplankton $\delta^{15} \mathrm{~N}$ values may even exceed those of higher trophic level species within a grazing food chain. This is observed, for instance, in another freshwater lake, Lough Erne (UK), where mixed zooplankton species have higher $\delta^{15} \mathrm{~N}$ values than carnivorous fish (Maguire and Grey 2006; Keaveney and Reimer 2012). Thus, the larger $\delta^{15} \mathrm{~N}$ value of the smaller eel, when compared with the larger eel, is consistent with the smaller eel being part of a detritus food chain, including POC, while the larger eel is part of a grazing food chain.

The ${ }^{14} \mathrm{C}$ age of DOC $(730 \pm 20 \mathrm{yr})$ at Lake Schwerin is significantly older than that of POC (620 \pm $30 \mathrm{yr}$ ). Given the agreement of ${ }^{14} \mathrm{C}$ ages for both the grazing and the detritus food chains with those of DIC and POC, respectively, there is no clear evidence that DOC constituted a major nutrient contributor to Lake Schwerin's food web.

The ${ }^{14} \mathrm{C}$ dates from the single specimen of zebra mussel from Lake Ostorf are considerably older than those at Lake Schwerin. This was not anticipated given the proximity of both lakes. Comparing isotopic results from the zebra mussel specimens in lakes Schwerin and Ostorf, significant differences are also noticeable. Although the $\delta^{13} \mathrm{C}$ values of flesh are similar in both specimens, the $\delta^{15} \mathrm{~N}$ value of the Ostorf specimen (14.6\%) is considerably higher than the Schwerin specimen (8.1\%o). Significant variations in $\delta^{15} \mathrm{~N}$ values of primary producers have been observed in lakes located in close proximity, reflecting differences in catchment area and nutrient source (Vander Zanden et al. 2005). Elevated $\delta^{15} \mathrm{~N}$ values are typically associated with farming sources. In the near vicinity of Lake Ostorf, there is a large farmed peat area towards the southeast. The more negative zebra mussel shell $\delta^{13} \mathrm{C}$ value from Lake Ostorf (-7.5\%), when compared with the value from the Lake Schwerin specimen (-3.6\%), reflects a higher carbonate contribution from the oxidation of organic material, probably allochthonous. Furthermore, the presence of significantly ${ }^{14} \mathrm{C}$-depleted organic matter is also suggested by the ${ }^{14} \mathrm{C}$ age difference between the Ostorf zebra mussel flesh $(1120 \pm 20 \mathrm{yr})$ and shell (1060 $\pm 30 \mathrm{yr}$ ), showing, in contrast with Lake Schwerin, the contribution of metabolic DOC towards zebra mussel flesh (Roditi et al. 2000).

The ${ }^{14} \mathrm{C}$ results from lakes Schwerin and Ostorf have important consequences for the identification and correction of human dietary reservoir effects. The observation of $2{ }^{14} \mathrm{C}$ distributions at Lake Schwerin suggests that local reservoir effects could be represented by a bimodal distribution. However, some caution should be taken as previous studies have demonstrated a wider span of variability from freshwater contexts, even within the same species (Fischer et al. 2007; Keaveney and Reimer 2012; Fernandes et al. 2012b). A larger fish sample set from Lake Schwerin could reveal a wider distribution of ${ }^{14} \mathrm{C}$ ages, reflecting different dietary preferences among or within species.

Likely differences in individual human dietary preferences, for instance in preferred aquatic species or fishing location, imply that human dietary reservoir effects from freshwater contexts are particularly difficult to predict. These aspects, and variations in fish isotopic values, combine to offer a par- 


\section{Routing Within Aquatic Food Web of Lake Schwerin}

ticularly complex framework. This contributes to explain why, in the prehistoric individuals from the Ostorf burial, there was no clear relationship between the elevated $\delta^{15} \mathrm{~N}$ collagen values and individual reservoir effects (Olsen et al. 2010). Additionally, likely past variations in local reservoir effects, associated with varying environmental conditions, have to be considered. Therefore, great caution has to be taken in the determination of local freshwater reservoir effects aiming at human dietary reservoir effect correction.

\section{CONCLUSIONS}

${ }^{14} \mathrm{C}$ measurements on fish and mussels samples from lakes Schwerin and Ostorf demonstrated the presence of large and variable freshwater reservoir effects in this region. These results are consistent with previous ${ }^{14} \mathrm{C}$ and archaeological research that showed the existence of large human dietary reservoir effects at the prehistoric burial site of Ostorf.

The distribution of ${ }^{14} \mathrm{C}$ measurements on faunal and floral samples from Lake Schwerin was constrained within the ${ }^{14} \mathrm{C}$ concentrations of water DIC and POC, confirming the working hypothesis. The clustering of ${ }^{14} \mathrm{C}$ results suggests the identification of clearly separated grazing and detritus food chains.

The large reservoir effect differences between lakes Schwerin and Ostorf, in spite of their close proximity, highlight the difficulties in establishing a single reference reservoir effect in freshwater contexts. Such large spatial variability, combined with the contrasting ${ }^{14} \mathrm{C}$ concentrations for different food groups at Lake Schwerin, the isotopic variability in fish species, and likely temporal variations, constitute important challenges to the establishment of chronologies relying on the ${ }^{14} \mathrm{C}$ dating of local human bone material.

\section{ACKNOWLEDGMENTS}

The authors wish to acknowledge the help of Olaf Nehlich who provided access to isotopic measurements on fish flesh and to Chris Harrod for his insightful feedback. Research funding is provided by the German Research Foundation (Deutsche Forschungsgemeinschaft) within the framework of the Priority Program SPP 1400 and the Graduate School "Human Development in Landscapes" of the German Excellence Initiative.

\section{REFERENCES}

Allen YC, Thompson BA, Ramcharan CW. 1999. Growth and mortality rates of the zebra mussel, Dreissena polymorpha, in the Lower Mississippi River. Canadian Journal of Fisheries and Aquatic Sciences 56(5):748-59.

Armitage PD, Cranston PS, Pinder LCV. 1995. The Chironomidae: Biology and Ecology of Non-Biting Midges. London: Chapman \& Hall.

Arneborg J, Heinemeier J, Lynnerup N, Nielsen HL, Rud N, Sveinbjörnsdóttir ÁE. 2000. Change of diet of the Greenland Vikings determined from stable carbon isotope analysis and ${ }^{14} \mathrm{C}$ dating of their bones. Radiocarbon 41(2):157-68.

Ascough PL, Cook GT, Dugmore AJ, Barber J, Higney E, Scott EM. 2004. Holocene variations in the Scottish marine radiocarbon reservoir effect. Radiocarbon 46(2):611-20.
Ascough PL, Cook G, Church MJ, Dunbar E, Einarsson Á, Dugmore AJ, Perdikaris S, Hastie H, Friðriksson A, Gestsdóttir H. 2010. Temporal and spatial variations in freshwater ${ }^{14} \mathrm{C}$ reservoir effects: Lake Mývatn, northern Iceland. Radiocarbon 52(2-3):1098-112.

Ascough PL, Cook GT, Hastie H, Dunbar E, Church MJ, Einarsson Á, McGovern TH, Dugmore AJ. 2011. An Icelandic freshwater radiocarbon reservoir effect: implications for lacustrine ${ }^{14} \mathrm{C}$ chronologies. The Holocene 21(7):1073-80.

Attayde J, Ripa J. 2008. The coupling between grazing and detritus food chains and the strength of trophic cascades across a gradient of nutrient enrichment. Ecosystems 11(6):980-90.

Baker SM, Levinton JS, Kurdziel JP, Shumway SE. 1998. Selective feeding and biodeposition by zebra mussels and their relation to changes in phytoplankton 


\section{$R$ Fernandes et al.}

composition and seston load. Journal of Shellfish Research 17(4):1207-13.

Barak NA-E, Mason CF. 1992. Population density, growth and diet of eels, Anguilla anguilla L., in two rivers in eastern England. Aquaculture Research 23(1):59-70.

Bayne BL, Iglesias JIP, Hawkins AJS, Navarro E, Heral M, Deslous-Paoli JM. 1993. Feeding behaviour of the mussel, Mytilus edulis: responses to variations in quantity and organic content of the seston. Journal of the Marine Biological Association of the United Kingdom 73:813-29.

Beaudoin CP, Tonn WM, Prepas EE, Wassenaar LI. 1999. Individual specialization and trophic adaptability of northern pike (Esox lucius): an isotope and dietary analysis. Oecologia 120(3):386-96.

Cook GT, Bonsall C, Hedges REM, McSweeney K, Boroneant V, Pettitt PB. 2001. A freshwater diet-derived ${ }^{14} \mathrm{C}$ reservoir effect at the Stone Age sites in the Iron Gates Gorge. Radiocarbon 43(2):453-60.

Cranford PJ, Hill PS. 1999. Seasonal variation in food utilization by the suspension-feeding bivalve molluscs Mytilus edulis and Placopecten magellanicus. Marine Ecology Progress Series 190:223-39.

Dewar G, Pfeiffer S. 2010. Approaches to estimating marine protein in human collagen for radiocarbon date calibration. Radiocarbon 52(4):1611-25.

Dörner H, Benndorf J. 2003. Piscivory by large eels on young-of-the-year fishes: its potential as a biomanipulation tool. Journal of Fish Biology 62(2):491-4.

Drimmie RJ, Aravena R, Wassenaar LI, Fritz P, Hendry MJ, Hut G. 1991. Radiocarbon and stable isotopes in water and dissolved constituents, Milk River aquifer, Alberta, Canada. Applied Geochemistry 6(4):381-92.

Erlenkeuser H, Cordt HH, Simstich J, Bauch D, Spielhagen RF. 2003. DIC stable carbon isotope pattern in the surface waters of the southern Kara Sea, Sep. 2000. In: Stein R, Fahl K, Fütterer DK, Galimov EM, Stepanets OV, editors. Siberian River Run-off in the Kara Sea. Amsterdam: Elsevier. p 91-110.

Fernandes R, Rinne C, Grootes PM, Nadeau M-J. 2012a. Revisiting the chronology of northern German monumentality sites: preliminary results. In: Hinz M, Müller J, editors. Siedlung Grabenwerk Großsteingrab. Frühe Monumentalität und Soziale Differenzierung 2. Bonn. p 87-103.

Fernandes R, Bergemann S, Hartz S, Grootes PM, Nadeau M-J, Melzner F, Rakowski A, Hüls M. 2012b. Mussels with meat: bivalve tissue-shell radiocarbon age differences and archaeological implications. Radiocarbon 54(3-4):953-65.

Fischer A, Olsen J, Richards M, Heinemeier J, Sveinbjörnsdóttir ÁE, Bennike P. 2007. Coast-inland mobility and diet in the Danish Mesolithic and Neolithic: evidence from stable isotope values of humans and dogs. Journal of Archaeological Science 34(12): 2125-50.
Franck L, Laurent E, Marc de R, Stephane P, Maurice R. 2010. Influence of food supply on the $\delta^{13} \mathrm{C}$ signature of mollusc shells: implications for palaeoenvironmental reconstitutions. Geo-Marine Letters 30(1):23-34.

Frost WE. 1954. The food of pike, Esox lucius L., in Windermere. Journal of Animal Ecology 23(2):339-60.

Fry B, Sherr EB. 1984. $\delta^{13} \mathrm{C}$ measurements as indicators of carbon flow in marine and freshwater ecosystems. Contributions in Marine Science 27:13-47.

Geyh MA. 2000. An overview of ${ }^{14} \mathrm{C}$ analysis in the study of groundwater. Radiocarbon 42(1):99-114.

Geyh M, Schotterer U, Grosjean M. 1998. Temporal changes of the ${ }^{14} \mathrm{C}$ reservoir effect in lakes. Radiocarbon 40(2):921-31.

Gillikin DP, Lorrain A, Bouillon S, Willenz P, Dehairs F. 2006. Stable carbon isotopic composition of Mytilus edulis shells: relation to metabolism, salinity, $\delta^{13} \mathrm{C}$ DIC and phytoplankton. Organic Geochemistry 37(10):1371-82.

Gillikin DP, Hutchinson KA, Kumai Y. 2009. Ontogenic increase of metabolic carbon in freshwater mussel shells (Pyganodon cataracta). Journal of Geophysical Research 114(G1): doi: 10.1029/2008JG000829.

Gordon JE, Harkness DD. 1992. Magnitude and geographic variation of the radiocarbon content in Antarctic marine life: implications for reservoir corrections in radiocarbon dating. Quaternary Science Reviews 11(7-8):697-708.

Hall BL, Henderson GM. 2001. Use of uranium-thorium dating to determine past ${ }^{14} \mathrm{C}$ reservoir effects in lakes: examples from Antarctica. Earth and Planetary Science Letters 193(3-4):565-77.

Harrod C, Grey J. 2006. Isotopic variation complicates analysis of trophic relations within the fish community of Plußsee: a small, deep, stratifying lake. Archiv für Hydrobiologie 167(1-4):281-99.

Harrod C, Grey J, McCarthy TK, Morrissey M. 2005. Stable isotope analyses provide new insights into ecological plasticity in a mixohaline population of European eel. Oecologia 144(4):673-83.

Havens KE, East TL. 1997. Carbon dynamics in the "grazing food chain" of a subtropical lake. Journal of Plankton Research 19(11):1687-711.

Hedges REM, Reynard LM. 2007. Nitrogen isotopes and the trophic level of humans in archaeology. Journal of Archaeological Science 34(8):1240-51.

Hessen DO, Andersen T, Lyche A. 1990. Carbon metabolism in a humic lake: pool sizes and cycling through zooplankton. Limnology and Oceanography 35(1): 84-99.

Higham T, Warren R, Belinskij A, Härke H, Wood R. 2010. Radiocarbon dating, stable isotope analysis, and diet-derived offsets in ${ }^{14} \mathrm{C}$ ages from Klin-Yar site, Russian North Caucasus. Radiocarbon 52(2):653-70.

Hope D, Billett MF, Cresser MS. 1994. A review of the export of carbon in river water: fluxes and processes. Environmental Pollution 84(3):301-24. 


\section{Routing Within Aquatic Food Web of Lake Schwerin}

Hübner H, Richter W, Kowski P. 1979. Studies on relationships between surface water and surrounding groundwater at Lake Schwerin (German Democratic Republic) using environmental isotopes. In: Isotopes in Lake Studies. Vienna: IAEA. p 95-102.

Katzung G. 2004. Geologie von Mecklenburg-Vorpommern. Stuttgart: Schweizerbart'sche Verlagsbuchhandlung.

Keaveney EM, Reimer PJ. 2012. Understanding the variability in freshwater radiocarbon reservoir offsets: a cautionary tale. Journal of Archaeological Science 39(5):1306-16.

Kennedy M, Fitzmaurice P. 1968. The biology of the bream Abramis Brama (L) in Irish waters. Proceedings of the Royal Irish Academy B 67:95-157.

Krienke H-D, Obst K. 2011. Raben Steinfeld und die Eiszeit: Landschaftsentwicklung und geologische Sehenswürdigkeiten südöstlich von Schwerin. In: Brandenburgische Geowissenschaftliche Beiträge 1/2. Cottbus. p 107-23.

Ladle M, Bass JAB, Jenkins WR. 1972. Studies on production and food consumption by the larval Simuliidae (Diptera) of a chalk stream. Hydrobiologia 39: 429-48.

Lammens EHRR, de Nie HW, Vijverberg J, van Densen WLT. 1985. Resource partitioning and niche shifts of bream (Abramis brama) and eel (Anguilla anguilla) mediated by predation of smelt (Osmerus eperlanus) on Daphnia hyalina. Canadian Journal of Fisheries and Aquatic Sciences 42(8):1342-51.

Lammens EHRR, Frank-Landman A, McGillavry P, Vlink B. 1992. The role of predation and competition in determining the distribution of common bream, roach and white bream in Dutch eutrophic lakes. Environmental Biology of Fishes 33(1-2):195-205.

Landmeyer JE, Stone PA. 1995. Radiocarbon and $\delta^{13} \mathrm{C}$ values related to ground-water recharge and mixing. Ground Water 33(2):227-34.

Lanting JN, van der Plicht J. 1998. Reservoir effects and apparent ${ }^{14} \mathrm{C}$-ages. Journal of Irish Archaeology 9: 151-65.

Levin I, Hesshaimer V. 2000. Radiocarbon-a unique tracer of global carbon cycle dynamics. Radiocarbon 42(1):69-80.

Lillie M, Budd C, Potekhina I, Hedges R. 2009. The radiocarbon reservoir effect: new evidence from the cemeteries of the middle and lower Dnieper basin, Ukraine. Journal of Archaeological Science 36(2): 256-64.

Lorenzoni M, Corboli M, Dorr AJM, Giovinazzo G, Selvi S, Mearelli M. 2002. Diets of Micropterus salmoides Lac. and Esox lucius in Lake Trasimeno (Umbria, Italy) and their diet overlap. Bulletin Francais de la peche et de la pisciculture 365-366:533-47.

Maberly SC, Spence DHN. 1983. Photosynthetic inorganic carbon use by freshwater Plants. Journal of Ecology 71(3):705-24.
Maguire CM, Grey J. 2006. Determination of zooplankton dietary shift following a zebra mussel invasion, as indicated by stable isotope analysis. Freshwater Biology 51(7):1310-9.

Mann KH. 1988. Production and use of detritus in various freshwater, estuarine, and coastal marine ecosystems. Limnology and Oceanography: Methods 33(4): 910-30.

McNichol AP, Osborne EA, Gagnon AR, Fry B, Jones GA. 1994. TIC, TOC, DIC, DOC, PIC, POC-unique aspects in the preparation of oceanographic samples for ${ }^{14} \mathrm{C}$-AMS. Nuclear Instruments and Methods in Physics Research B 92(1-4):162-5.

Mehner T, Diekmann M, Bramick U, Lemcke R. 2005. Composition of fish communities in German lakes as related to lake morphology, trophic state, shore structure and human-use intensity. Freshwater Biology 50(1):70-85.

Nadeau M-J, Schleicher M, Grootes PM, Erlenkeuser H, Gottdang A, Mous DJW, Sarnthein JM, Willkomma H. 1997. The Leibniz-Labor AMS facility at the Christian-Albrechts-University, Kiel, Germany. $\mathrm{Nu}$ clear Instruments and Methods in Physics Research B 123(1-4):22-30.

Nadeau M-J, Grootes PM, Schleicher M, Hasselberg P, Rieck A, Bitterling M. 1998. Sample throughput and data quality at the Leibniz-Labor AMS facility. Radiocarbon 40(1):239-46.

Nadeau M-J, Grootes PM, Voelker A, Bruhn F, Duhr A, Oriwall A. 2001. Carbonate ${ }^{14} \mathrm{C}$ background: Does it have multiple personalities? Radiocarbon 43(2A): 169-76.

Nagelkerke LAJ, Sibbing FA. 1996. Efficiency of feeding on zebra mussel (Dreissena polymorpha) by common bream (Abramis brama), white bream (Blicca bjoerkna), and roach (Rutilus rutilus): the effects of morphology and behavior. Canadian Journal of Fisheries and Aquatic Sciences 53(12):2847-61.

Nixdorf B, Hemm M, Hoffmann A, Richter P. 2004. Dokumentation von Zustand und Entwicklung der wichtigsten Seen Deutschlands. Berlin. German Federal Environmental Agency.

Olsen J, Heinemeier J, Lübke H, Lüth F, Terberger T. 2010. Dietary habits and freshwater reservoir effects in bones from a Neolithic NE German cemetery. Radiocarbon 52(2):635-44.

Olsson IU. 1980. Radiocarbon dating of material from different reservoirs. In: Suess HE, Berger R, editors. Radiocarbon Dating. Los Angeles: University of California Los Angeles Press. p 613-8.

Philippsen B. 2012. Variability of freshwater reservoir effects - Implications for radiocarbon dating of prehistoric pottery and organisms from estuarine environments [PhD thesis]. Aarhus University.

Pomeroy LR. 1980. Detritus and its role as a food source. In: Barnes RK, Mann KH, editors. Fundamentals of Aquatic Ecosystems. Blackwell Science. p 84-102. 


\section{$R$ Fernandes et al.}

Post DM. 2002. Using stable isotopes to estimate trophic position: models, methods, and assumptions. Ecology 83(3):703-18.

Poulain C, Lorrain A, Mas R, Gillikin DP, Dehairs F, Robert R, Paulet Y-M. 2010. Experimental shift of diet and DIC stable carbon isotopes: influence on shell $\delta^{13} \mathrm{C}$ values in the Manila clam Ruditapes philippinarum. Chemical Geology 272(1-4):75-82.

Robson H, Andersen S, Craig O, Fischer A, Glykou A, Hartz S, Lübke H, Schmölckef U, Heron C. 2012. Carbon and nitrogen isotope signals in eel bone collagen from Mesolithic and Neolithic sites in northern Europe. Journal of Archaeological Science 39(7):200311.

Roditi HA, Fisher NS, Sanudo-Wilhelmy SA. 2000. Uptake of dissolved organic carbon and trace elements by zebra mussels. Nature 407(6800):78-80.

Schoeninger MJ, DeNiro MJ. 1984. Nitrogen and carbon isotopic composition of bone collagen from marine and terrestrial animals. Geochimica et Cosmochimica 48:625-39.

Schoeninger M, DeNiro M, Tauber H. 1983. Stable nitrogen isotope ratios of bone collagen reflect marine and terrestrial components of prehistoric human diet. Science 220(4604):1381-3.

Shishlina NI, van der Plicht J, Hedges REM, Zazovskaya EP, Sevastyanov VS, Chichagova OA. 2007. The catacomb cultures of the northwest Caspian steppe: ${ }^{14} \mathrm{C}$ chronology, reservoir effect, and paleodiet. Radiocarbon 49(2):713-26.

Shishlina NI, Zazovskaya EP, van der Plicht J, Hedges REM, Sevastyanov VS, Chichagova OA. 2009. Paleoecology, subsistence, and ${ }^{14} \mathrm{C}$ chronology of the Eurasian Caspian steppe Bronze Age. Radiocarbon 51(2): 481-99.

Smith FA, Walker NA. 1980. Photosynthesis by aquatic plants: effects of unstirred layers in relation to assimilation of $\mathrm{CO}_{2}$ and $\mathrm{HCO}_{3}{ }^{-}$and to carbon isotopic discrimination. New Phytologist 86(3):245-59.
Tierney D, Donnelly RE, Caffrey JM. 1999. Growth of bream, Abramis brama (L.), in Irish canals and implications for management. Fisheries Management and Ecology 6(6):487-98.

Vander Zanden MJ, Vadeboncoeur Y, Diebel MW, Jeppesen E. 2005. Primary consumer stable nitrogen isotopes as indicators of nutrient source. Environmental Science \& Technology 39(19):7509-15.

Vaughn CC, Hakenkamp CC. 2001. The functional role of burrowing bivalves in freshwater ecosystems. Freshwater Biology 46(11):1431-46.

Venturelli PA, Tonn WM. 2005. Invertivory by northern pike (Esox lucius) structures communities of littoral macroinvertebrates in small boreal lakes. Journal of the North American Benthological Society 24(4):90418.

Vuorio K, Tarvainen M, Sarvala J. 2007. Unionid mussels as stable isotope baseline indicators for long-lived secondary consumers in pelagic food web comparisons. Fundamental and Applied Limnology 169(9): 237-45.

Weidel BC, Carpenter SR, Kitchell JF, Vander Zanden MJ. 2011. Rates and components of carbon turnover in fish muscle: insights from bioenergetics models and a whole-lake ${ }^{13} \mathrm{C}$ addition. Canadian Journal of Fisheries and Aquatic Sciences 68(3):387-99.

Wetzel RG. 1995. Death, detritus, and energy flow in aquatic ecosystems. Freshwater Biology 33(1):83-9.

Zhou A, Chen F, Wang Z, Yang M, Qiang M, Zhang J. 2009. Temporal change of radiocarbon reservoir effect in Sugan Lake, northwest China during the Late Holocene. Radiocarbon 51(2):529-35.

Zigah PK, Minor EC, Werne JP, Leigh McCallister S. 2012. An isotopic $\Delta^{14} \mathrm{C}, \delta^{13} \mathrm{C}$, and $\delta^{15} \mathrm{~N}$ investigation of the composition of particulate organic matter and zooplankton food sources in Lake Superior and across a size-gradient of aquatic systems. Biogeosciences 9(9):3663-78. 